\title{
E-mail enviado aos Arquivos Brasileiros de Oftalmologia em 2 de julho de 2006.
}

\section{Assunto: Brasil Colônia}

Algo que vem me aborrecendo muito na nossa revista é essa mania de artigos em língua bretã. Domino o idioma mas acho isso tudo sentimento de inferioridade. Concordo com a tradução do cerne em inglês e talvez no portal da revista a tradução completa. Afinal, o que vem depois dos Arquivos?

Celso Henrique Cortes Chaves

São Paulo - SP

\section{Congresso da Sociedade Brasileira de Retina e Vítreo}

\section{2 a 14 de Arril de 2007}

\section{Uberlândia - MG}

Tel.: (34) 3231-4500

E-mail: falecom@retina2007.com.br

Home-page: www.retina2007.com.br 